\section{EMBRYRIDDLE}

Aeronautical University

SCHOLARLY COMMONS
Journal of Aviation/Aerospace

Education \& Research

Volume 17

Number 2 JAAER Winter 2008

Article 6

Winter 2008

\title{
Study of an Aviation Design Supportability Course for Engineering and Technology
}

J. Mark Thom

Tracy Gerbracht

Follow this and additional works at: https://commons.erau.edu/jaaer

\section{Scholarly Commons Citation}

Thom, J. M., \& Gerbracht, T. (2008). Study of an Aviation Design Supportability Course for Engineering and Technology. Journal of Aviation/Aerospace Education \& Research, 17(2). https://doi.org/10.15394/ jaaer.2008.1448

This Article is brought to you for free and open access by the Journals at Scholarly Commons. It has been accepted for inclusion in Journal of Aviation/Aerospace Education \& Research by an authorized administrator of Scholarly Commons. For more information, please contact commons@erau.edu. 


\title{
STUDY OF AN AVLATION DESIGN SUPPORTABILITY COURSE FOR ENGINEERING AND TECHNOLOGY
}

\author{
J. Mark Thom and Tracy Gerbracht
}

\begin{abstract}
The following reports on a study examining a typical aeronautical/aviation engineering senior design course, and examines how an aviation technology based course applying the elements of logistics support analysis might be taught concurrently. The study examines the content of a typical senior engineering design course, the required content for a technology based logistics support analysis course, and analyzes the overlaps. Over the course of the study the methods and limitations of engineering design were observed by the technology researchers and were used to formulate the content of an aviation logistics course.
\end{abstract}

\section{Introduction}

With the dramatic revision in engineering accreditations standards created by ABET 2000 environment (ABET was formerly the Accreditation Board for Engineering and Technology), technology programs are being expected to become more integrated into the engineering efforts of industry. The applied knowledge taught in technology programs has for years filled the gaps left as engineering became more scientific and analytical, and with less handson application. (Thom, 2004) The experiential knowledge and skills of the technology graduate has been increasingly recognized as more and more technology programs are granted accreditation as engineering technology programs. The aircraft structures, systems, and operations knowledge taught in aviation programs in the United States today, can play an important role in engineering technology. The following study details one way in which direct aviation maintenance and operations knowledge can be used to develop synergies with the engineering design process at the educational level.

\section{What is logistics?}

Historically the discipline of logistics has been a military term, but that has changed over the last twenty years. J. W. Langford in his book Logistics Principles and Applications defines logistics as, "the application of engineering, operational and managerial skills to provide a product with prerequisite quality, reliability, maintainability and supportability; and to sustain safe and cost-effective utilization of that product for its intended purpose throughout its projected service life." There a more business oriented definition of the term has begun to emerge. In Benjamin S. Blanchard's books Logistics Engineering and Management a decidedly more engineering aspect of the term can be found when he says that logistics is "a composite of all support considerations necessary to assure the effective and economical support of a system or equipment at all levels of maintenance for its programmed life cycle." Logistics in truth covers the planning of a process or a system from inception to conclusion. It has been popularized in retail marketing by the modern method of product shipping and distribution in order to meet a zero inventory strategy, and by the "just in time for delivery" business strategy. However, shipping and distribution are only one small aspect of the concept of a forward planning supply and utilization strategy that dates back to the Roman Empire.

The elements of making logistics happen in a modern aerospace system include: definition of system requirements, training, information technology, facilities, test and measurement, support personnel, spare parts determination, supply chain and inventory, technical data, packaging and transportation, and logistics data information. (Blanchard, 2004) Each of these elements is demanding in and of its self, and if the elements are only managed 
individually they individually flourish at the expense of the other elements. Logistics is a technical management function that provides planning for any system from the initial design, through implementation, and finally disposal. By using logistics, a manufacturer can identify high cost drivers early in the design and build process, and then identify cost effective alternative methods. The manufacturer can also use logistics to increase a product's reliability, maintainability, failure rate, repair rate, and other logistical elements. By optimizing these elements, the cost of ownership is reduced and safety can be increased.

The cost effective options may be evaluated for an entire aircraft, or for systems and components within the aircraft. Subsystems or components within the aircraft can be identified as high cost drivers, and in some cases these subsystems can be redesigned, replaced, or eliminated, thus reducing the cost of ownership for the entire aircraft.

These kinds of analyses are often most effectively done by persons with practical application experience, but who at the same time have the ability to communicate and analyze in engineering terms. The aviation technologist from a four year bachelor's degree program is suited to this task of analysis given their intimate training on aircraft systems, study of manufacturing and repair procedures, and level of college education.

The goal of this study was to examine whether undergraduate students in aviation technology could work directly with students in an aeronautical engineering senior design course, and overlay the concepts of the Logistics Support Analysis (LSA) over the engineering design work prepared in the engineering course.

\section{Logistics and Aviation/Aerospace}

The aviation and aerospace industry would fail to function without the results of the logistics analysis performed on aerospace vehicles and their components. Flight operations, and even the associated direct aircraft maintenance, represents only the tip of an industrial iceberg where the vast majority of the planning and support efforts lay "below the waterline" and out of sight of the operators of the aircraft. Aviation and aerospace is dependent on the up front design analysis and the data resulting from the various reliability and maintainability analyses. Without logistics analysis, accurate critical path and failure analyses would not exist. Without logistics, providing the maintainability and supportability forecasting, aircraft designs could not be supported over the fifty to one hundred year life spans of modern aviation fleets. Such analyses require insight into the design requirements, the technical support capabilities available, and the manufacturing techniques economically available. These last two areas have become difficult for design engineers to understand (Thom, 2004) and are more often the expertise of students of aviation technology and aviation engineering technology. A design engineer who is knowledgeable about the operation environment is a valuable employee. The engineering community often refers to this holistic engineering concept as "systems engineering". While there is a clear consensus about the need for engineers and technologists who are well versed in systems engineering, there is much less consensus about how to accomplish that goal. (Thom, 2004) In the past, attempts have been made to expose the design engineers to the operational requirements of the systems on which they work. In a correspondence to the researchers, Dr. Benjamin Blanchard shares this example:

"As an example, this rather typical scenario was realized by the United States Air Force (USAF).many years ago, and in the mid 1980s the USAF established a "Blue Two Program" (out of Dayton [Ohio]) with the objective of inviting lead engineers in industry to various USAF [bases] to experience some of the operational conditions at a typical base. I [Dr. Blanchard] was invited to participate in of these trips, along with twenty contractors, and we visited bases in Okinawa [Japan] and Korea. Of the twenty high-level lead engineers responsible for aircraft design and development in industry, only one of them had ever been on an operational base prior to this trip. While the situation has undoubtedly improved somewhat since, there is still the great likelihood that engineers, particularly in the defense industry, will be designing equipment without actually having experience any time in the field" (B. Blanchard, personal communication, August 7, 2003).

When taking the engineer to the products is not practical, logistical analysis can fill the gap. Logistics can not provide an engineer with first hand knowledge, but it can aide the engineer with answers and bring analysis from experts in other areas. It can also help to put what would otherwise be antidotal evidence and tribal knowledge into quantifiable terms that can be factored into a design analysis.

If logistics is a way to improve a product, one question that must be answered is who is responsible for logistics functions? Two obvious possibilities are the engineer or the technologist. However, logistics does not fall neatly within the purview of either of them. This is an area where the two disciplines overlap. Identifying the more desirable candidate 
Study of an Aviation Design

can be difficult. In the case of the design course outlined in this current study, there is little difference in experience between the engineering student and the technology student (B. Blanchard, personal communication, May 16, 2003). This is because the engineer is most familiar with the design requirements of the system but is less familiar with the operational requirements, and the technology student knows operational requirements but is less familiar with the design constraints. However in "the real world" the actual knowledge differences become more pronounced.

If an aviation technology logistics course is to be developed that would co-exist with a senior engineering design course, it is necessary to understand how the engineering design course is conducted. Much of the decision on the viability of success for a proposed concurrent logistics course depends on the interface between the logistics course and the senior engineering design course. Not only do the goals need to be similar, but also the path to reach those goals needs to be similar. If the technology based logistics course is going to study maintainability factors, then the engineering class needs to supply the maintainability data to the logistics class. It is this sort of synergy envisioned as being necessary to create the most successful relationship.

\section{Considerations for the study}

In the current study there were several considerations in making the determination of whether the logistics course could be conducted as desired. The first hurdle was the need for the logistics students to harvest useful engineering data to perform a logistics analysis. The backbone of the logistics course was the logistics analysis. This analysis drove the topics in the logistics course. It also provided immediate and useful feedback to the students, both logistic and engineering.

The second hurdle was a need for the logistics students to absorb the engineering data and provide feedback to the engineering students. Once the logistics students received the engineering data, they used that data to create an analysis. But the job of the technologist was not considered complete until some sort of feedback to the engineering students was provided. The analysis could have been a full Logistics Support Analysis (LSA) or it could have been a simple and quick comparison between two options to determine which option provided the greatest reliability, i.e. a trade study. But even the simple act of providing the results of the analysis was not enough. The results had to be provided in such a manner the engineering students could understand the relevance to the design. Complete feedback also contained proof of the validity of the results of the logistical analysis. This way the engineering students not only knew what the impacts on the design might be, but could base decisions on the logistics feedback with confidence.

The third hurdle was the engineering student's need to obtain some benefit from the logistics support analysis provided. They needed to see if there were changes made to the design based on information provided by the logistics students. In order to expect buy in from the engineering students, the engineers needed to see how an LSA tangibly and measurably improved their design. If engineers created the best designs without logistics influence, proof of the need for logistics would be flimsy at best. One goal was to show the engineering students avenues of resources and support beyond their own discipline.

Creation of goals for the technology logistics course

The intent for logistics course resulting from this current study was several-fold. It was envisioned as a way to allow engineering and technology students to interact in order to allow the engineering students to utilize the experiential skills of the technologist. It would also allow the technology students to have first hand access to learn from the structured engineering design process. Even if the courses did not meet formally together the intent would be to be able to provide a cross flow of data to allow the engineering students to make better design decisions and to allow the logistics students to be able to work an iterative analysis that evolved as the design of the system evolved. If nothing else, the intent was to create a climate to teach both the engineer and the technologist how to communicate with one another in their respective professional languages, and to carry this skill into the aerospace design and manufacturing environment. The result of the work done by the technology logistics students would be the creation of a Logistics Support Analysis (LSA) data analysis that could detail the significant cost, manufacturing, reliability, and critical elements of the system design.

According to Blanchard (1992), there are four objectives to the Logistics Support Analysis (LSA):

1) Helps create the initial supportability requirements.

2) Helps evaluate alternative systems or equipment design configurations.

3) Helps evaluate specific logistic support requirements.

4) Measures and evaluates the operating system in terms of its effectiveness and supportability. Not only does the analysis help design a better system, but it also provides a way to evaluate the system. In this manner there is no need to "guess" if the 
system is working correctly, there is objective evidence to prove its effectiveness.

The LSA process also evaluates different system/equipment design configurations. This process might entail topics such as: alternative repair policies, specific reliability and maintainability characteristics, or comparison of two or more off the shelf equipment items to replace a unique system design (Blanchard, 1992). It is this functionality that allows logistics plans to be flexible, and prevents designers from being locked into a predetermined box. True exploration to possible dead ends can occur, and definitive answers can be given as to their potential.

Another goal of the LSA is to evaluate a design based on logistic support requirements. After design data is available, many things are able to be determined; such as test and support equipment, inventory requirements, training requirements, personnel skills, spare and repair parts, technical data, facilities, transportation, handling requirements, and computer resources. These results are identified through the logistic support analysis record (LSAR) or the maintenance analysis documentation (Blanchard, 1992). These are the factors that, if not identified and quantified early in the design process, can spell the failure of the program.

A diagram detailing the LSA process within the system design process is included as Figure 1. Steps six, eight and eleven comprise the major logistics steps in the system design process. 


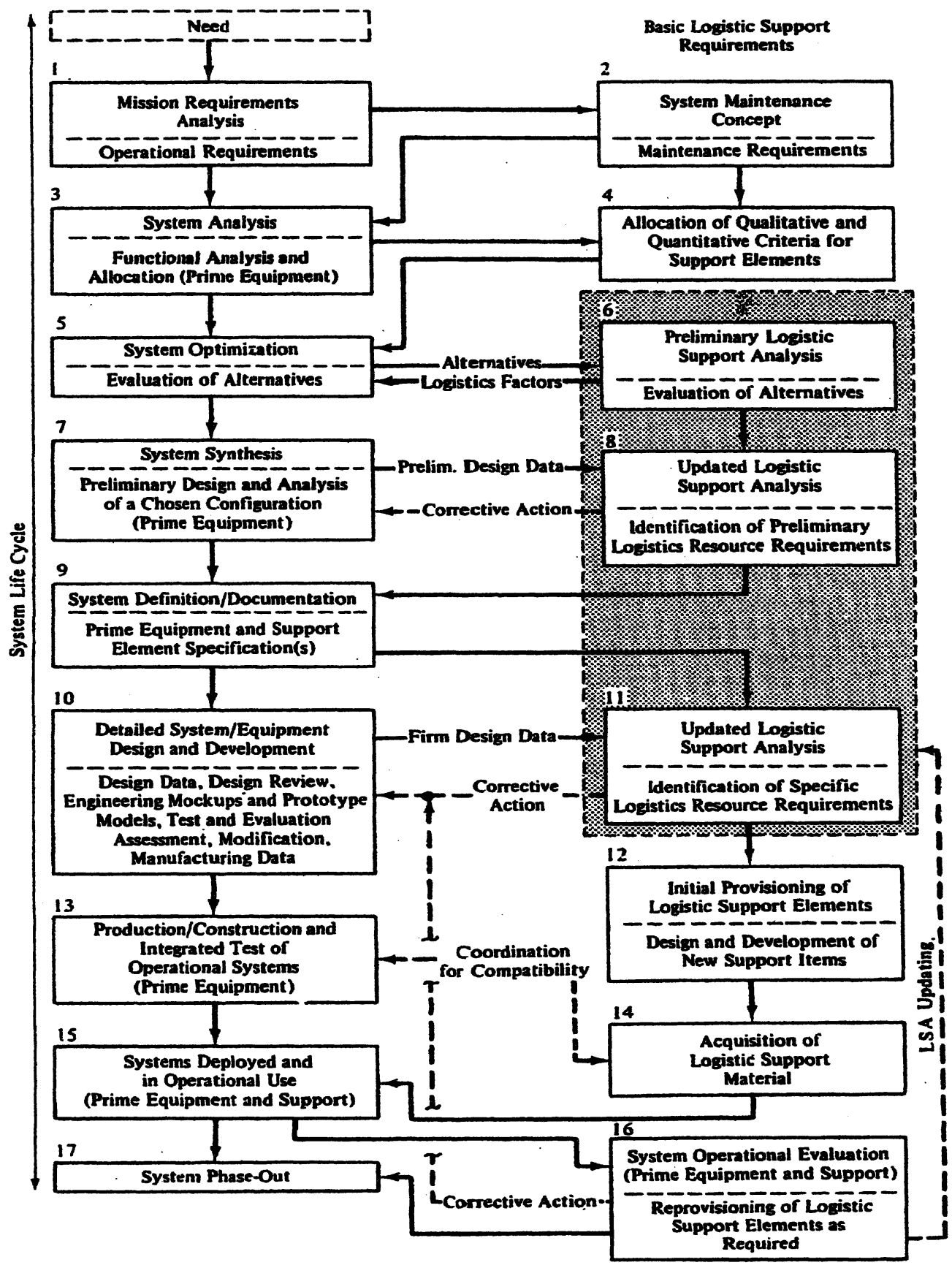

Figure 1 (Blanchard, p 19, 2004) 


\section{Methodology}

In order to identify the criteria and procedures required to construct a successful course five elementary activities were to be preformed:

1. Observe engineering design education courses directly,

2. Analyze previous design course structures and content,

3. Analyze previous logistics course structures and content,

4. Collect data from logistics text books,

5. Determination of structure, content, and goals for the proposed concurrent engineering/technology class.

Observe engineering design education courses

Much of the decision on the viability of success for a logistics course depended on the interface between the logistics course and the senior engineering design course. Throughout two semesters of studying a typical design engineering course the researchers attended all of the scheduled lectures and labs. The researchers documented the daily topics covered in the course and any problems encountered by the students. The questions asked by the engineering students were noted as well as places where the engineering students expressed a desire for logistics based information was noted. The researchers documented the daily topics covered in the course and any problems encountered by the students. This information was summarized and used to create the course comparison spreadsheet found in Appendix A.

\section{The researchers as participants}

Since the end result of the logistics course was to provide engineering students with logistics support data and to understand how they would use it, it did not seem prudent to maintain a status as silent observers. By simply observing, it would have been possible to overlook some of the problems that might be associated with trying to create an interface been logistics students and engineering students. Therefore the authors of this study, along with the two other technology based researchers, formed a logistics support team to allow the aviation technology researchers to interact with the engineering students. This team provided the engineering students with input to their designs based on the team's experience in the design and manufacturing industry. In this way the researchers could be involved in the process in a manner much like how they envisioned the future technology logistics students to interact. Based on the questions received from the students throughout the semester the engineering students found this to be a valuable resource.

\section{The content of the engineering courses}

As seen in Appendix A, the courses all began with having the engineering students respond to a Request for Proposal (RFP), followed by having the students do trade off studies, constraint diagrams, carpet plots, and historical reviews of aircraft performance in order to settle on a basic aircraft design. The results were presented in a Preliminary Design Review (PDR). Following that, the engineering students would move on to detailed design work focusing on structures, stability, propulsion, and aerodynamics. The status of the detailed design work would be presented weekly and would culminate in a Critical Design Review (CDR). Following a successful CDR, the engineering students would be given a go ahead to either build the aircraft (subscale), or in some semesters to complete further detailed analysis of the aircraft to verify mission capability. Regardless of whether an aircraft was built or whether a detailed mission study was completed the timing and pacing of the courses remained nearly identical over the semesters examined in this study.

The engineering students were divided into design teams and the students looked at the operational requirements of the RFP. They did brief studies to determine what kind of design options might be available to fulfill the mission. These possible alternatives were presented to the course instructors in a formal presentation where the pros and cons of the alternatives were discussed. During this detailed engineering analysis period the instructors in the engineering course would work with the student groups to help them utilize the analytical tools the students had been given over their academic career. During this time there was very little detailed engineering analysis regarding structures or systems. Most of this time was spent collecting and defining performance data and the factors affecting the performance data.

In a real engineering effort there would have been some detailed design done at this point. Key technology limitations would have been identified, off the shelf or design by similarity concepts would have been identified and quantified. In an actual design effort in industry it would be this initial pass at selected detailed design which would begin locking in the costs, technology required, and limitations for construction and maintenance of the aircraft. In the student design course this data definition did not happen. The engineering students assumed that the construction technology would be available, possible, functional, and cost effective.

The detailed design work in the engineering course 
often did not include significant detailed analysis of the construction aspects of the aircraft. In general, it involved gathering materials and beginning a trial and error construction of the aircraft. As the students developed skills at aircraft construction they then began to document and analyze what they considered to be the significant technological problems with the aircraft design. In the classes where no actual aircraft was built, a detailed analysis following the PDR was generally done to produce a marketability study for the aircraft or an operational assessment for the aircraft. In these cases the engineering students had little or no empirical knowledge, or understanding of how to get historical data to perform a detailed market analysis or operational assessment of the aircraft.

Each group of engineering students was expected to do a formal presentation at the end of the semester detailing their design activity. The week by week activities of these courses was detailed in the analysis spreadsheet in Appendix A.

\section{Analysis of previous Aeronautical Engineering design classes}

In addition to studying ongoing engineering design courses, the researchers gathered historical data from eight more semesters of engineering design course activities by looking at the research notes and syllabi from another researcher (Thom, 2004) who was doing a five year longitudinal study of these engineering design course activities. In this way data from these other semesters, taught by four different engineering instructors, could be compared to the semesters directly observed to determine if what was observed was typical. From these notes, which detailed the daily activities of the design course, more substantiation was gained on the activities in the engineering course in general. These activity notes from previous researchers included daily course topics, briefs on engineering students' questions, and observation data on information the engineering students desired lacked.

The summary of this work was compiled in analysis spreadsheet and included in Appendix A. The comparisons revealed that the semester studied was indeed typical of an engineering senior design course in this curriculum regardless of the semester, the projects chosen, or the instructor who taught the course.

A comparative study of previous logistics courses

Historical data was also gathered regarding the teaching of logistics courses. A series of logistics courses had been taught at the local community college for over six years. The instructors teaching in this program were adjunct instructors who worked full time in industry performing logistics duties for aerospace companies or for U.S. defense contractors. Courses taught by more than one instructor were examined, and the information gathered reflected many semesters' worth of experiences at teaching the logistics elements. The information gathered from a review of these courses indicated in what order, and on what kind of schedule, the elements of logistics analysis should be taught.

In general, these courses were conducted in a manner consistent with the plan of study recommendations of the Society of Logistics Engineers (1992). The courses typically began with an overview of probability as a foundation for the topics of reliability and maintainability. After that the topics included aspects and measures of system availability for use. Availability topics such as mean time between failure, natural and induced failure rate, mean time to repair, and system availability were quantified. The methods for analyzing systems were developed including the factors involved in evaluating failure modes and determining criticality. Finally the methods for evaluating the cost of ownership of the systems were quantified, and methods for examining life cycle costs were established. There were no specific courses in the plan of study guides from the Society of Logistics Engineers that provided the type of concurrent course sought for this study. The plan of study guides were used in this study to extract the key concepts desired, and to try to find a way to package them into a single course compatible with being taught concurrently with an engineering design course.

Over the course of studying these course topics the logistics students were taught about the two-way links between the engineer and the technologist who often does the logistics analysis. The logistics students were taught that certain data had to come from the engineer, and that, in return, certain data needed to be made available for the engineers to use in design decisions. There was, however, little education provided to the logistics students on how the engineers used the data provided, how the engineers produced the date they supplied to the logistics process, or the limitations on the engineers in these processes. The ways that the design process worked affected the type of data the logistics analyst received. The assumptions used in the creation of the engineering data also affected the assumptions the logistics analyst should have made.

By performing the logistics analysis in a vacuum of knowledge about the engineering process, the assumptions made for the resulting logistics analysis are less accurate. Additionally, by not understanding the engineering process, the logistician can wind up asking engineering the wrong 
questions, or can ask the right questions as the wrong time. In either case the logistician may wind up unable to develop an accurate analysis.

The information gathered from a review of the logistics course is also provided in Appendix A.

\section{Logistics text book review}

The researchers conducted a review of possible textbooks for a potential logistics course. All textbooks available from text book publishers at the time were examined. This was done to find a textbook which contained information compatible with the proposed course. Secondly, this review provided input to the researchers that the content and organization of the proposed logistics course was in line with the views of well known contemporary logistics experts. The methodology of the textbook review is beyond the scope of this paper. It should be noted however that the text book eventually selected was influenced by the pattern of information taught in the engineering classes using the content and teaching patterns identified in the spreadsheet in Appendix A.

\section{Determining the Organization of the proposed Logistics Course}

Separate columns in the spreadsheet shown in Appendix A were created for the development of a new logistics course. The order and content of the information in these columns allowed for the teaching of the logistics concepts and allowed for inclusion of data from the engineering courses. Time was factored in for the technology based logistics students to gather data from engineering, perform an analysis of the data, and provide feedback to engineering. As part of the analysis process, columns were added in the spreadsheet, which included the formulaic requirements for the logistics course on a week by week basis, as well as detailed information needed to the technology based logistics students. For the purposes of this paper these detailed columns have been omitted from Appendix A for clarity.

\section{Analysis of the design and logistics course comparisons}

The spreadsheet shown in Appendix A was used as the graphical interface tool, not only to display the end data but to allow for the side by side qualitative assessment of the course contents. Analysis of the spreadsheet was done on an ongoing basis using 42-inch wide plotter outputs of the spreadsheet. Because of the limited power of a desktop computer monitor to provide a "big picture" view of a large spreadsheet, only the paper plotter versions were used in the analysis.

Appendix A shows a spreadsheet comparison of the logistics courses and the engineering design courses laid out side by side, on a week by week schedule over a standard fifteen week semester. Appendix $A$ is admittedly a complex document for the inclusion in this paper, and the temptation was to break up its findings, to scatter portions of it throughout this paper, and to simply summarize its findings. The authors feel however to do that would be to detract from the intent of using graphical tools to present complex information as is advocated by Dr. James Evans, in his textbooks The Management and Control of Quality. The spreadsheet was the heart of the study and the authors of this study felt that it was important for presentation here.

The spreadsheet compares:

1) Logistics courses more than five years by two different instructors,

2) Ten semesters of engineering courses with four different instructors,

3) The textbook topics available from the textbook selected,

4) Statements of what the students in the logistics classes were expected to know and do at prescribed times in the semester.

On paper this match up between the historical logistics courses and the historical design courses seemed to match up at an acceptable level. During the first part of the semester where the engineers were working on the system definition the technology students would be working on understanding the foundational probability elements needed for the reliability and maintainability studies to come. As the engineering students developed their first pass at a design proposal during the PDR, the logistics students would be ready to take that information and perform a low level analysis of the critical drivers in the system. By the time the engineering students reached the CDR, they would have been iterating the design and the logistics students would have been using those iterations to better define the cost and criticality elements. When the engineering students moved to the construction phase in one course or in the operational assessment phase in the second course, the logistics students would then be at work using the known data to prepare a "cradle to grave" life cycle cost evaluation of the system. The logistics students would present the life cycle analysis at the same time the engineering students performed their final flights or final operational assessments. In an ideal setting the engineering students would have logistics data to support their design decisions and to make design changes.

Limitations in the engineering process

From the time spent in the engineering design classes it 
became apparent that the engineering students had a tremendous amount of information to distill in their fifteen weeks of class. Organizing and quantifying the engineering data alone was daunting for them, and given that there was often a lack of direct experiential knowledge of aircraft materials and systems their tasks became even more difficult. As the engineering students worked to gain the knowledge they needed to do their analysis it became evident that it was not possible for them to provide enough detailed data early enough in the semester to allow the logistics students to do a useful logistical analysis. Configuration control of the engineering designs was not possible at a level at which the logistics students would be able to provide feedback in a timely enough fashion to be of benefit to the design process. Ideally the courses would work in a design spiral where the engineering students develop a design, the design is analyzed, and the results of the analysis are fed back to the engineers for design modifications. The issue then became that the engineering students could not provide consistent data arrival schedules and could not provide enough detailed data for the logistics analysis. While this discovery was not anticipated it was, however, important to this study to have understood why it occurred. It was important to understand why the timeline of the engineering design course was not compatible with the timeline of the logistics course. When on paper it appeared that the two should co-exist, but in the real world they did not, an understanding of why was required. This was important not just from a theoretical standpoint. The reasons why had implications on the expectations that a logistics student would have on the engineering design process. To know the limitations of the design process allowed for better assumptions in the logistics process. Knowledge of where and how the data gaps occurred were valuable in allowing the logistics course developers understand the constraints of the engineering design process, and to be able to instill that information into the logistics course. It was just as important for the student of the logistics class to understand the limitations of the design process as it was for the engineers to be able to understand the logistics process. Armed with first hand information of the limitations of the engineering senior design course, the development of a functioning logistics course was still.

\section{Alternatives for Engineering/Technology Interaction}

The inability to operate a logistics course concurrently in parallel with a design course was anticipated from the beginning. While concurrency was a goal, it would have been naive to have based the success of the study on that outcome. There were several options for compensating for the limitations found in the data delivery from the engineering design course. Option one might have been to specially re-work each of the two classes into a specific design and support analysis course. But this would have affected the plans of study of two separate programs at the university. Option two might have been to force a standard structure for the engineering course that made the course dependent on the logistics analysis. But this would have required interfering with the design engineering education process, and imposing impractical limits on the design course instructors. Option three might have been to limit the scope of the engineering course to areas where data from the logistics analysis directly drove the designs. Again, that would have interfered with the engineering education. Based on direct observation of the engineering design courses these options were not advised. To shackle the design course to the logistics analysis would have taken away the inventive spirit of the design process, and limited the creativity of the engineering students. The researchers advocated instead a forth option.

This fourth option would be to run the logistics course separate from the engineering design course. This would allow the logistics students to do an analysis on engineering designs from previous semesters where the data would be as complete as possible. While this defeated the one goal of direct engineering-technology interaction, it still provided a way to provide trusted and usable data.

The proposed solution

Instead of feeding back the results of a design analysis in the same semester, the results of these analyses could be provided back to future engineering design classes to allow them to make future design choices given historical data from previously analyzed designs. Review of historical data was stressed in engineering as one of the elements of good design in engineering. By providing analysis and data on previous semesters' designs, the future engineering students would be able to make better choices based historical data prepared by the aviation technology students. This would then in turn teach the engineering design students about the availability of the logistical data. Using the structure of the logistics support analysis would provide the validity of data discussed previously. It would provide data in a usable format compatible for easy inclusion into the aircraft design, which was on of the preferred outcomes.

A drawback of this system is that there is not the direct face to face contact between the aeronautical engineers and the aviation technologists. However, by having the aviation technologists as the authors of useful historical data for future design classes, it can prompt the engineers to seek out 
technology input in the future. For the technology students taking the logistics course without the engineers, it remains up to the technology instructors to take the knowledge gained working with engineering and impart to the technology students the design process and its limitations.

\section{Conclusions}

From a technology education standpoint, valuable information was gained about the methods and limitations of the engineering design education process. The ability to study first hand the way that the design process was taught, and the difficulties of the student engineers had in assimilating the technical pieces, provided insights into the kind of support that technology could provide to the engineering process. These insights allowed not only for the design of a logistics course, but also provided first hand information on what the role of an aviation technology program might play as an engineering technology program in the post ABET 2000 environment. In the end it was determined that in this case the required fluid nature of the engineering classes did not provide the timeliness and completeness of the engineering data needed for a real time logistics analysis. This study advocates having the aviation technology students analyze final designs and to provide historical databases for future semesters of engineering design students to use for their required "historical analysis". Feedback gathered from the engineering design students during this study showed that they welcomed the technical and logistical inputs from the researchers who actively participated in the design processes. This indicated that the logistical inputs from the technology students would be valued and welcomed additions to the engineering design educational process. $t$

J.M. Thom is an associate professor at Purdue University. While there he has overseen a certificate course in logistics, has taught design life cycle cost analysis courses, and has been the principle investigator for three studies on engineering education. Professor Thom holds an A\&P certificate and teaches aviation maintenance and engineering technology, and has taught graduate courses in quality management. He has worked a field engineer for a major aerospace corporation, and in design engineering and integrated logistics support activities.

T. L. Gerbracht is a customer support engineer for the Pratt \& Whitney engine division of United Technologies. She has worked as a customer support representative and as a logistics engineer for McDonnell Douglas and The Boeing Company. She holds an A\&P certificate, and became involved in the study of engineering technology education and the logistics processes while working to complete her Masters Degree in Technology through Purdue University. 


\section{References}

Blanchard, B. (2004). Logistics Engineering and Management $\sigma^{\text {th }}$ ed. Englewood Cliffs, NJ: Prentice Hall.

Blanchard, B. (1992). Logistics Engineering and Management. Englewood Cliffs, NJ: Prentice Hall.

Blanchard, B. (2003). Personal communication, May 16, 2003.

Evans, J. and Lindsay, W. (2005). The Management and Control of Quality. Mason, OH: Thompson Southwestern

Langford, J. W. (1995). Logistics Principles and Applications. New York: McGraw-Hill.

Society of Logistics Engineers (1992). Logistics Education and Training Program Curricula. New Carrollton, Maryland, Logistics Education Foundation.

Thom, M.A. (2004). Perceptions of Practitioners and Engineering Educators and Students Regarding Requisite Skills for Effective Design of Complex Systems. Unpublished Masters Thesis, Purdue University. 


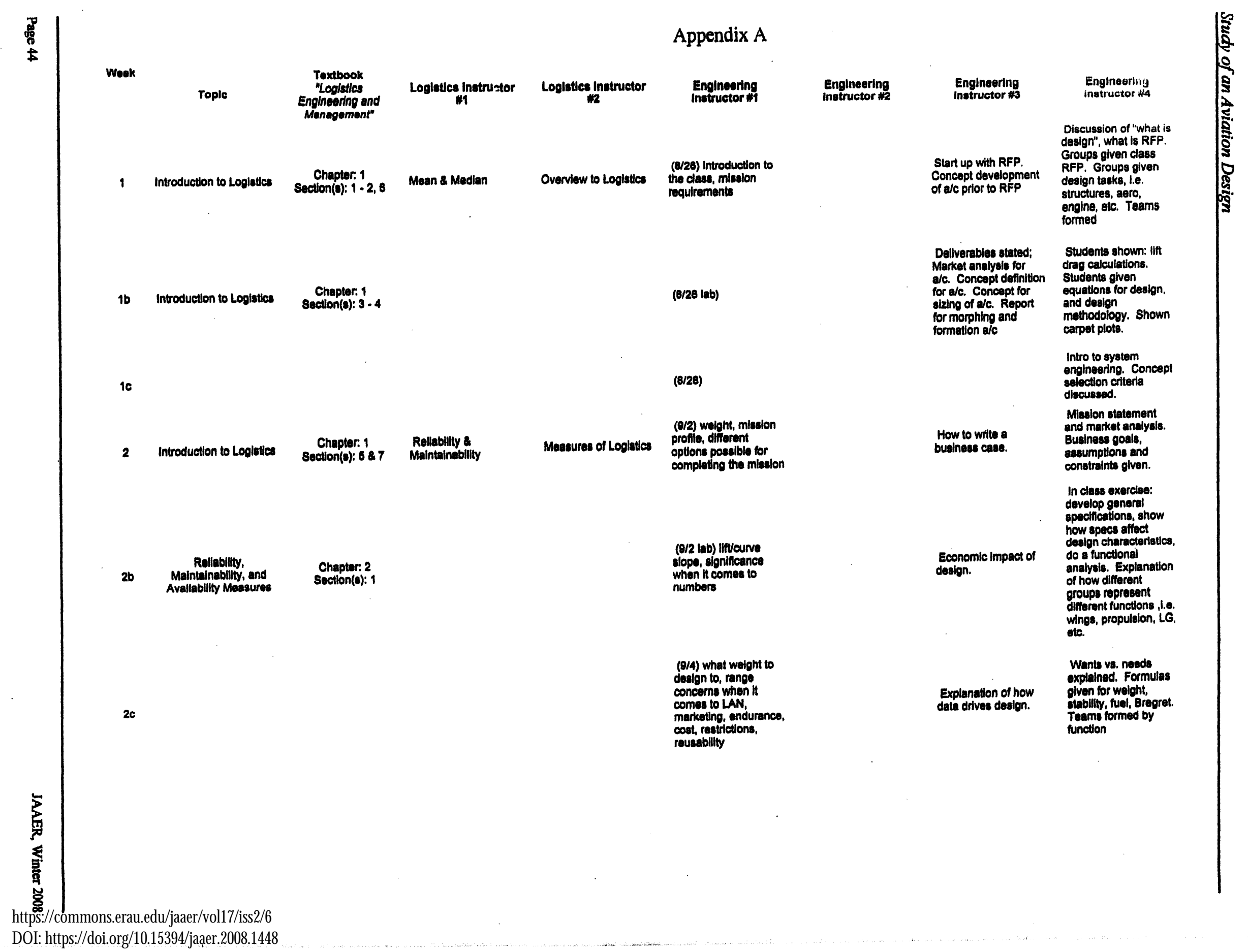


Thomand Gerbradt Study of an Avidion Design Supportdbility Carsefor Engineering

3 Rellabillty Malintainabillty, and
Avallabillty Mocioure:

Chaptar: 2
section(B): 1 Avallability Q Quallty
Asaurance

Measures of Logistles Appendix A (9/9) software requirements, pod, welght, Power. Propellers. Propellars, Torque, Wing Loeding Powor Loading

( $9 / 0 \mathrm{lab}$ ) expected Iife, operating time, Contraint Analyele, Conotralint, Enduranea Constrint, Enourancas Requined

36

Rallabillty,
Malntainebllty, and
Avaliablilty Moasures

4 Rallablilty, Malntalnabillty, and
Avallabillty Moaeures

Chapter 2 Section(0):2

Human Factore Engincering \& safoty Engineering

Syotem Operationa Requiromonts and Syatem Maintenanes
Concept Rellabillty,
Malntalnabillty, and $\begin{gathered}\text { Chaptar: } 2 \\ \text { Section(a): } 3\end{gathered}$

Rellabllity,

$4 c$ Rellabilty, Maintainablilty, and $\quad$ Chaptor: 2
Section(s):
(8/11) pro/con of

choosing dealon too

you can bur",

downutream onfects of

chosen dedign

(O/16) Acpect Ratlo

Two Dimenalonal

Airfoll Data, Dras

Oowaldas Enclangy.

Skin Friotion

Number, Laminar

(e/16 lab) Team

concaptio Due, group

(8/18) toam
Polurn, Induced Drag

Paotor, Wolted Are

Coenincient, Reynold's

asalgnments, open
Lots of formulus yor design given to

students. Discusslon

of reasons why $a / c$

$\begin{array}{ll}\text { Set up for market } & \text { slzes and shapes } \\ \text { analyyla presentatlons } & \text { differ. Trade offs for } \\ \text { students present frrst } & \text { performance. } \\ \text { iteration business } & \text { Sensittilty discussed }\end{array}$

$\begin{array}{ll}\text { Set up for market } & \text { slzes and shapes } \\ \text { analyyla presentatlons } & \text { differ. Trade offs for } \\ \text { students present frrst } & \text { performance. } \\ \text { iteration business } & \text { Sensittilty discussed }\end{array}$

$\begin{array}{ll}\text { Set up for market } & \text { slzes and shapes } \\ \text { analyyla presentatlons } & \text { differ. Trade offs for } \\ \text { students present frrst } & \text { performance. } \\ \text { iteration business } & \text { Sensittilty discussed }\end{array}$

minstivly dlavas:

misolon weight vs.

to define mission.

TSFC - Ilte/drag- Mn -

Show students how

anginearing concopts

esch other.

empty welght, otc

affects on sizing.

Alroil aerodynamlce: kinds of drag.

Groups to find weight of similar dealgns. Functione

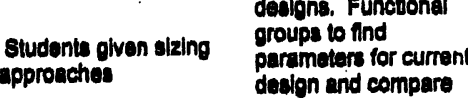
dealon and compare to similar dealons. Introduced.

Btudents present

Fual tractions and related concepts ve. misolon constraints.

Discuselon of what condilet of.

veluations. Range

\section{More welght vs.}

portormances

ve. wolght etc.

Studiants lierate

misalon ctatamont

glven what the have

thair deeden. 
Appendix A

6

ces and System Support

Chapter: 3
Section(s): 1 - 3

Contracting

Functional Analysis \& Requireme.nts Allocation

propeller design
parametere, propeller
dealgn eoftware
"gold.m, prob.m"

sb The Measures of
Logletica and Syotem Support

\section{Chapter: 3}

be

6 The Meabures of Chaptor. 3 Crittcal Path Analysis, Logietics and Syetem Section(0): 8 -7
Support The syatem Engineering Procees Chapter: 4

sc

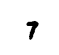

The Syetem Enginearing Proces: Chapter: 4

76

The Syetom Engineoring Process

Chapter: 4 Life Cycle Cont and
Dealgn Roviows
LSA

(9/23 lab) Prelliminary
Dealgn Revlewb

\section{(8/26) effective}

presentation, antennas

(9/30) open discusalon

(O/30 lab) Bizlng

Roviow

turbine ve aes

Modeling Proces

Teat
(10/2) propulation

(10/7) Dynamic
Students taught from Boeing and NASA.

\section{Students} presentations beg

Discussion of

huselege design.

Raymer doos not

and carmo neods well

oo It was defined here.

(Students have no

dealgn yot at this

Students are

supposed to bring

skelches this week.

Mout bing cad

Student show an actual trade off study.

First attempts 10 match mission with

Students presented information on QFD in order to organize wha tho customer wants alternetives on how to achieve those wants.

\section{Students present} alscreft by function aero, structures, propulelon, etc.

\section{Studonts generated} 20 skatches of alternative dealgns. and wore required to

Students are to supply baelc layout, first gueses el groses welgh bestc shape, carpol

\section{QDR formal}

presentations done by funetional groups. 
Thomand Gerbradt Study of an Avidion Design Supportdbility Carsefor Engineering

Appendix A

(10/14) No Classes Logistics and
Supportabllty Analysis $\begin{gathered}\text { Chapter, } 5 \\ \text { Sectlon(s): } 1\end{gathered}$ Faclittes and PHS\&T $\begin{gathered}\text { Logistics in Syste } m \\ \text { Design }\end{gathered}$

More QDR: engines layout, basic design, inlets, combustion ongine, tall ghape/size, chambers, turbines,

86 Logietics and

Chapter: 5 Supportablity Analyols Section(s): 2

$8 c$

Loglestles and
Supportablity Analysis Chapter. 5
Sectlon(s): 3

\section{Inventory}

Managoment

Personnel

9b Supportablitty Analysis $\quad \begin{gathered}\text { Chapter: } 5 \\ \text { Section(0): } 4\end{gathered}$

$9 c$

10

Logistics in Systom Design and

$10 b$

Support \& Toe:

Equlpmont

Chaptor: 8
Section(8): 1
(10/14 lab) No

Clacses

(10/16) Struetures and

Weights Roview

(10/21) propellor plich,

control functions.

Structures Roviow

(10/21 lab)

Aerodynamices Review

(10/23) Propulaion
Roviow

Logistles Technical

Documentation

Spring Broak

(10/28) Propulalon wing shape/size. thrust, metrics

Students presen

trade off studies of no

performance litems.

Questions about

wher proposuly

designs can sectually

structures (wings.

tuse, attach, etc.) is

discussed

Specifications for

performance galns of

cormallon night aro

Groups are forced to

Prelminary bellevable plek one of their

Prellman alrcrain designs and

lock it in. Formal

rawinge are

Landing gear and

landing gear

presented.

Constrain dlagrams

with things like wing

loading vs. thrust to

weight rations are

T.O. diatance is

discousead. Engine

aliframe is disecussed.

Intilal Intomal layout is

presented. Lo config

is presented. Analysis

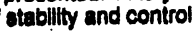

Students present

stablitty and control

Students prosent

information.

enalyels, tail size, CG,

onger stress, tonalon

and compression,

aspoct ratio, static

Students are to have

rofined all dealgn

propertios; wing, lall

engine, L.G. 


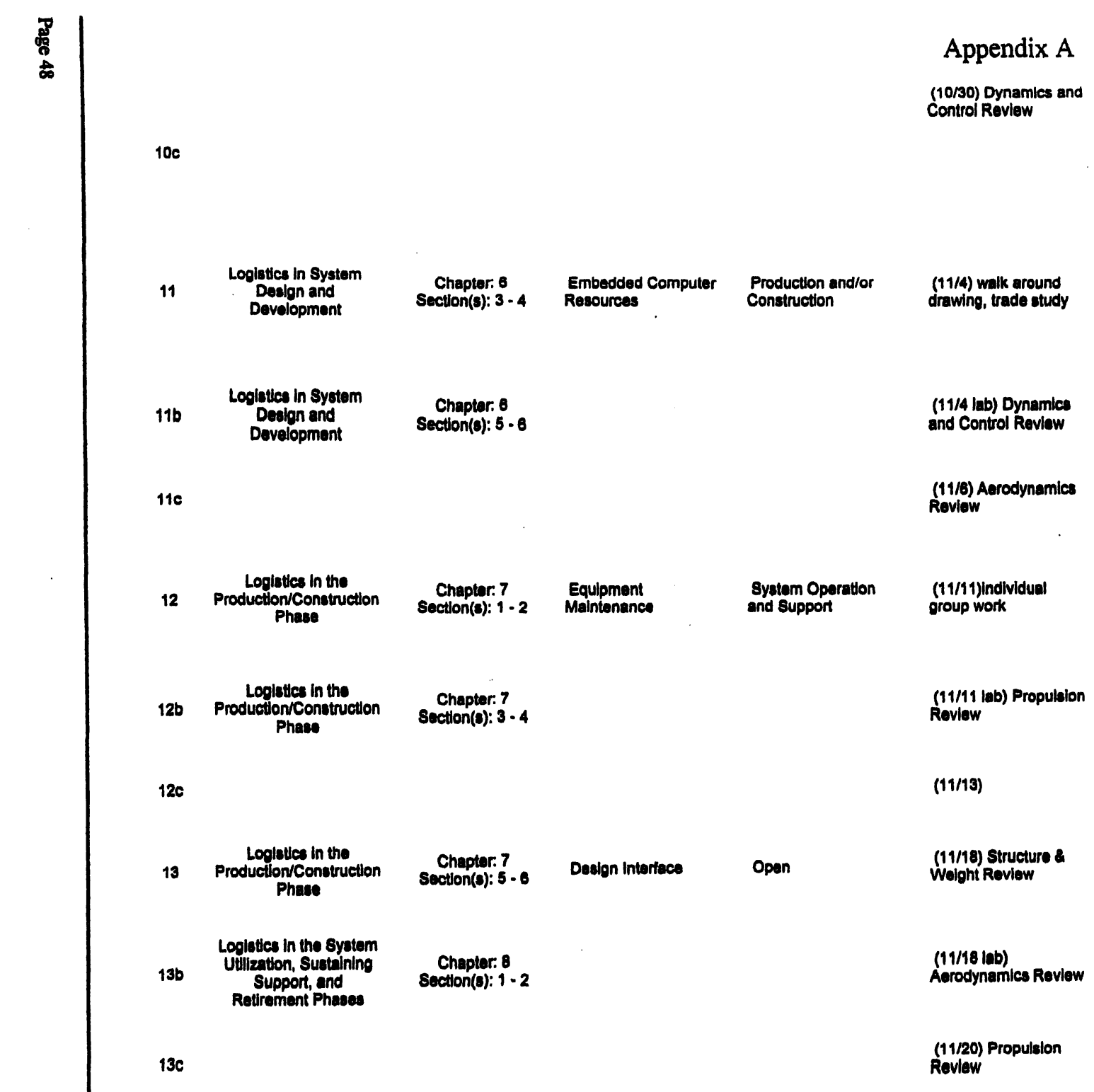


14

Logistics in the System

zation, sustaining Support, and
Retroment Phases

$14 b$

Logiettes Management $\begin{gathered}\text { Chapter } 8 \\ \text { Section(o): } 1.2\end{gathered}$

$14 c$

16

Logletice Management Section(o): 3 - 5 Teat

$15 b$

Logietices Management

Chapter $\theta$
Section(s): 8

$15 c$

Appendix A

(11/25)

(11/25 lab)

(11/27) No Classes

(12/2) Dynamics and

Clase Trip

Col Roviow

(12/2 lab) Dynamles and Control Roview,

(12/4) Cout Reviow
TBD

TBD

More presentations of aircraft design choices

TBD

TBD

TBD

TBD
Final design review.

Students presen

everything to

Customers include

faculty panels, as well

as USAF visitors. 
